\title{
Perbedaan Kecerdasan Interpersonal Pada Remaja dengan Orangtua Lengkap dan Tidak Lengkap
}

\author{
Dewi Yarni, Yuliana Intan Lestari \\ Fakultas Psikologi UIN Sultan Syarif Kasim Riau \\ email: yuliana_intanlestari@yahoo.com
}

\begin{abstract}
Abstrak
Kecerdasan interpersonal adalah kecerdasan yang meliputi kemampuan untuk mengenali dan membuat perbedaan antara perasaan, kepercayaan, keinginan orang lain, mampu menjalin hubungan yang baik dengan orang lain, dan mempertahankan relasi yang telah dibangun. Setiap remaja memiliki latar belakang keluarga yang berbeda, ada remaja yang memiliki orangtua lengkap dan tidak lengkap. Tujuan dari penelitian ini untuk melihat perbedaan kecerdasan interpersonal pada remaja yang memiliki orangtua lengkap dengan dan tidak lengkap, dan mengetahui bagaimana kecerdasan interpersonal yang memiliki orangtua lengkap dengan yang tidak lengkap. Subjek dalam penelitian ini adalah remaja yang duduk di bangku Sekolah Menengah Atas (SMA) yang berada di Kecamatan Sungai Batang berjumlah 185 subjek yang terdiri dari 100 remaja yang memiliki orangtua lengkap dan 85 remaja yang memiliki orangtua tidak lengkap. Metode analisis data dalam penelitian ini menggunakan uji perbedaan yaitu Independen Sampel T-Tes. Pada hasil uji hipotesis diketahui uji t hitung sebesar 6,394 dan nilai signifikansinya sebesar 0,000. Dari hasil penelitian ini diketahui bahwa terdapat perbedaan kecerdasan interpersonal pada remaja yang memiliki orangtua lengkap dan tidak lengkap.
\end{abstract}

Kata kunci: Kecerdasan Interpersonal, Remaja Orangtua Lengkap dengan Remaja Orangtua Tidak Lengkap

\section{The Differences of Interpersonal Intelligence In Adolescents Who Have A Parent Complete and Incomplete}

\begin{abstract}
Interpersonal intelligence is intelligence that involves the ability to recognize and make a distinction between feelings, beliefs, desires of others, able to establish good relationships with others, and maintaining relationships that have been built. Adolescent has a different family background, there are teens who have a parent complete and incomplete. The purpose of this study to look at the differences of interpersonal intelligence in adolescents who have a parent complete and incomplete, and knowing how interpersonal intelligence have a parent complete with incomplete. Subjects in this study were adolescents attending high school in Sungai Batang totally 185 subjects consisted of 100 adolescents who have a parent complete and 85 adolescents whose parents did not complete. Methods of data analysis in this study using Independent Sample T-Test. In the hypothesis, value of $t$ count equal is 6.394 and a significance value is 0.000 . From this research known that there are differences in interpersonal intelligence in adolescents who have a parent complete and incomplete.
\end{abstract}

Keywords: Interpersonal Intelligence, Adolescents with Complete Parents, Adolescents with Incomplete Parents.

\section{Pendahuluan}

Kehidupan masa remaja menarik untuk dibicarakan, hal ini disebabkan kompleksnya permasalahan yang muncul pada masa tersebut. Masa remaja merupakan salah satu periode dari perkembangan manusia. Masa ini merupakan masa perubahan atau peralihan dari masa kanak-kanak ke masa dewasa yang meliputi perubahan biologis, perubahan psikologis, dan perubahan sosial (Hurlock, 2002)

Berbagai macam problematika dalam kehidupan manusia menuntut remaja untuk mampu berinteraksi dan bersosialisasi den- gan baik terhadap orang lain dan lingkungan sekitarnya. Kemampuan berhubungan dengan orang lain menjadi hal yang sangat penting ketika seseorang ditempatkan dalam suatu lingkup sosial. Kemampuan ini akan menjadi salah satu penentu diterima atau tidaknya remaja dalam lingkungan sosialnya. Kemampuan menjalin hubungan sosial dengan orang lain biasa disebut dengan istilah kecerdasan interpersonal (Gadner dalam Safaria, 2005).

Pada masa remaja, kecerdasan interpersonal ini penting dimiliki remaja, hal ini dikarenakan menurut Misbach (2010) remaja dengan kecerdasan interpersonal yang tinggi 
memiliki kepekaan untuk memahami kebutuhan orang lain, memperhatikan perbedaan antar individu, mudah menjalin kerja sama, serta mengembangkan empati terhadap kesulitan orang lain. Potensi yang tinggi pada kecerdasan ini akan mempermudah seseorang berinteraksi dengan berbagai orang yang memiliki latar belakang yang berbeda.

Sebaliknya jika remaja tidak memilik kecerdasan interpersonal yang tinggi maka menurut Gardner (dalam Safaria, 2005) akan menyebabkan individu (termasuk remaja) sulit bergaul, sulit untuk dapat mengembangkan hubungan yang suportif dengan teman sebayanya, agresif, suka bertindak kasar, impulsif, atau sangat mementingkan egoismenya sendiri, sering terlibat konflik dan perkelahian dengan teman sebayanya, suka menyendiri, merasa kesulitan untuk berkomunikasi dengan orang baru, dan tidak suka berbaur dengan teman lainnya. Keluarga khususnya kedua orang tua memiliki peranan penting dalam membentuk kecerdasan interpersonal remaja (Yusuf, 2011).

Berdasarkan observasi yang dilakukan di sekolah dan di kediaman subjek pada tanggal 21-27 Februari 2014 terhadap remaja yang memiliki orangtua tidak lengkap ditemukan beberapa fakta: 4 dari 6 remaja cenderung mengalami kesulitan dalam membangun relasi dengan orang lain, hal ini telihat dari tingkah laku subjek yang bersikap acuh tak acuh dengan teman-teman atau orang-orang di sekitarnya, subjek sering berselisih paham dengan teman-temannya, jarang bergabung dengan orang lain, lebih banyak berdiam diri di kelas dan terlihat jarang berbicara dengan orang lain.

Bahkan salah seorang subjek yang diobservasi menunjukkan tingkah laku yang sering mengganggu teman-temannya, melanggar peraturan-peraturan yang ada seperti sering terlambat, terkadang berada di kantin saat jam belajar, dan sering berbicara kasar.

Selanjutnya hasil observasi yang peneliti lakukan terhadap remaja dengan orangtua lengkap yang peneliti lakukan baik di sekolah maupun di kediaman subjek pada tangggal 3-7 maret 2014 ditemukan fakta: 3 remaja mampu menunjukkan kemampuan dalam membangun relasi dengan orang lain, ini ditandai dengan remaja memiliki banyak teman, selalu terlihat gembira, aktif dalam kelas, aktif dalam organisasi sekolah, sering ikut berpartisipasi setiap acara di sekolah ataupun di lingkungan luar, sering berkumpul dengan teman-temannya dan sering membantu orang lain.

Kecerdasan interpersonal akan menentukan seseorang dapat diterima di lingkungan sosial atau tidak ditinjau dari lengkap tidaknya orang tua. Maka dari itu melalui penelitian ini akan terlihat perbedaan kecer- dasan interpesonal pada remaja yang memiliki orangtua lengkap dengan remaja yang memiliki orangtua yang tidak lengkap.

Menurut Anderson (1999) kecerdasan interpersonal adalah kecerdasan yang meliputi kemampuan untuk mengenali dan membuat perbedaan antara perasaan, kepercayaan, dan keinginan orang lain. Sementara itu menurut Gardner (dalam Armstrong, 2004) kecerdasan interpersonal ialah kemampuan mempersepsi dan membedakan suasana hati, maksud, motivasi, serta perasaan orang lain.

Adapun penjelasan dari ketiga dimensi kecerdasan interpersonal yaitu:

a. Social sensitivity, kemampuan remaja untuk mampu merasakan dan mengamati reaksi-reaksi atau perubahan orang lain yang ditunjukkannya baik secara verbal maupun non-verbal. Indikatornya yaitu: 1) Memiliki sikap empati, yaitu pemahaman tentang orang lain berdasarkan sudut pandang, prespektif, kebutuhan-kebutuhan, pengalaman-pengalaman orang tersebut. 2) Memiliki sikap prososial, yaitu tindakan moral yang harus dilakukan secara kultural seperti berbagi, membantu seseorang yang membutuhkan, bekerja sama dengan orang lain dan mengungkapkan simpati.

b. Social insight, yaitu kemampuan remaja untuk memahami dan mencari pemecahan masalah yang efektif dalam suatu interaksi social. Indikatornya yaitu; 1) Memiliki kesadaran diri, yaitu mampu menyadari dan menghayati totalitas keberadaannya di dunia seperti menyadari keinginan-keinginannya, cita-citanya, harapan-harapannya dan tujuan-tujuannya dimasa depan. 2) Memiliki pemahaman situasi sosial/etika sosial. 3) Memiliki keterampilan pemecahan masalah. Setiap individu membutuhkan keterampilan untuk memecahkan masalah secara efektif. Apalagi jika masalah tersebut berkaitan dengan konflik interpersonal.

c. Social Communication, yaitu kemampauan remaja untuk menggunakan proses komunikasi dalam menjalin dan membangun hubungan interpersonal yang sehat. Indikatornya yaitu; 1) Efektif dalam komunikasi. Komunikasi merupakan sarana yang paling penting dalam kehidupan manusia. 2) Mendengarkan efektif. Salah satu keterampilan komunikasi adalah keterampilan mendengarkan.

Menurut Safaria (2005) kecerdasan interpersonal menjadi penting karena pada dasarnya manusia tidak bisa menyendiri. Banyak kegiatan dalam hidup remaja terkait dengan orang lain. Remaja yang gagal mengembangkan kecerdasan interperson- 
alnya, akan mengalami banyak hambatan dalam dunia sosialnya dan mengakibatkan mereka mudah tersisihkan secara sosial.

Kelengkapan sebuah keluarga atau kelengkapan orangtua akan menghasilkan individu yang memiliki berbagai keterampilan perilaku yang akan membimbingnya dalam berinteraksi dengan lingkungan. Kelengkapan orangtua berdampak pada perkembangan sosial, kecerdasan (termasuk kecerdasan interpersonal), dan kepribadiannya.

Sedangkan menurut Dagun (2002) kondisi keluarga yang tidak utuh yang mengalami perceraian menyebabkan anak mengalami tekanan jiwa, aktivitas fisik menjadi agresif, kurang menampilkan kegembiraan, emosi tidak terkontrol, dan lebih senang menyendiri. Hal ini akan mengakibatkan masalah dalam berhubungan sosial dan juga pada perkembangan kecerdasan interpersonalnya. Menurut Qiami (dalam A'yuni, 2010) ada beberapa dampak atau pengaruh yang menimpa keluarga dan anak-anak ketika kehilangan salah satu orang tua baik ayah maupun ibu, pengaruhnya secara mental dan kejiwaan bisa berupa menurunnya kecerdasan, harapan dan semangat. Sedangkan pada perasaan akan muncul rasa gelisah, ketakutan, depresi bahkan kehilangan rasa belas kasih. Oleh karena itu hipotesis penelitian yang diajukan dalam penelitian ini adalah terdapat perbedaan kecerdasan interpersona antara remaja dengan orang tua lengkap dan yang tidak lengkap.

\section{Metode}

\section{Subjek}

Penelitian ini termasuk jenis penelitian kuantitatif (komparatif). Populasi adalah keseluruhan subjek penelitian (Arikunto, 2012). Adapun karakteristik populasi dalam penelitian ini yaitu:

a. Terdaftar sebagai siswa di SMA di Kec. Sungai Batang Kabupaten Indra Giri Hilir

b. Berusia antara 13-18 tahun

c. Duduk dikelas X-XI

Berdasarkan karakteristik populasi tersebut, maka jumlah populasi pada penelitian ini adalah 200 remaja yang memiliki orangtua lengkap dan 85 remaja yang memiliki orangtua tidak lengkap. Untuk menentukan jumlah sampel dalam penelitian ini, diambil berdasarkan pendapat Arikunto (2012), yaitu apabila subjek kurang dari 100 , lebih baik diambil semua sehingga penelitiannya merupakan penelitian populasi. Selanjutnya jika jumlah subjeknya besar dapat diambil antara $10-15 \%$ atau $20-25 \%$ atau lebih.

Mengacu kepada pendapat Arikunto di atas maka jumlah sampel yang diambil dalam penelitian ini adalah $50 \%$ remaja yang memiliki orang tua yang lengkap dan untuk remaja yang memiliki orang tua tidak lengkap semua dijadikan sampel penelitian. Dengan demikian jumlah sampel pada remaja dengan orangtua lengkap berjumlah 100 remaja dan 85 remaja dengan orangtua tidak lengkap.

\section{Pengukuran}

Pengumpulan data dalam penelitian ini menggunakan skala Likert yang telah dimodifikasi dengan menghilangkan jawaban netral untuk menghindari jawaban subjek ketengah (central tendency effect). Skala yang digunakan adalah skala kecerdasan interpersonal yang telah diujicobakan berdasarkan aspek-aspek kecerdasan interpersonal menurut Anderson (1999). Berdasarkan uji reliabilitas pada skala kecerdasan interpersonal diperoleh a sebesar 0,898. Dengan demikian koefesien reliabilitas semakin mendekati angka 1,00 maka skala kecerdasan interpersonal reliabel.

\section{Analisis Data}

Analisis data penelitian ini menggunakan Analisis Uji Perbedaan ( Independen Sample T-Test) yakni teknik statistik yang digunakan untuk menganalisis perbedaan antara kelompok subyek yang satu dengan kelompok subyek yang lain (Hair, dkk., 2006). Analisis dalam penelitian dilakukan menggunakan bantuan komputerisasi Statistical Product and Service Solutions (SPSS) 17.0 for Windows.

\section{Hasil}

Penelitian dilakukan di MA YPP Bin Dahlan, MA YPP Nurul Islam, MA YPP AlHuda Ilahiyah dan MA PP DDI Benteng. Subjek penelitian ini adalah remaja yang memiliki orangtua lengkap dan remaja yang memiliki orangtua tidak lengkap. Penelitian ini dilaksanakan pada tanggal 6 - 9 April 2015.

Dalam penelitian ini uji normalitas dilakukan pada satu variabel yaitu kecerdasan interpersonal melalui bantuan program SPSS 16.00 for Windows, dapat dilihat bahwa signifikansi (asyimp.sig) pada kecerdasan interpersonal pada remaja orangtua lengkap sebesar 0,093, selanjutnya pada remaja orangtua tidak lengkap 0,133. Nilai signifikansi yang diperoleh lebih besar dari taraf standar signifikansi 0,05, artinya dapat disimpulkan bahwa sebaran data penelitian normal.

Berdasarkan uji homogenitas, hasil perhitungan analisis Levene's Tes, signifikansi sebesar 0,199 dan nilai signifikansi tersebut lebih besar dari 0,05 atau (P>0,05). Dengan demikian, jika mengacu kepada pedoman penetapan pengujian homogenitas sebagaimana dikemukakan di atas, maka dapat disimpulkan data dalam penelitian ini homogen. 
Berdasarkan uji hipotesis yang dilakukan, hasil analisis diperoleh nilai t pada Equal Variances Assumed sebesar 6,394 dengan nilai signifikansi (p) 0,000 . Hasil tersebut menunjukkan bahwa $p<0,01$. Mengacu pada ketentuan penerimaan dan penolakan hipotesis sebagaimana telah dikemukakan di atas, maka hipotesis yang diajukan dalam penelitian ini yaitu terdapat perbedaan kecerdasan interpersonal pada remaja yang memiliki orangtua lengkap dengan remaja yang tidak memiliki orangtua lengkap diterima. Dengan demikian hasil uji analisis ini menyatakan hipotesis dalam penelitian ini diterima sebagai sebuah kesimpulan hasil penelitian.

Hasil data ditemukan kelompok sampel remaja yang memiliki orangtua lengkap memiliki kecerdasan interpersonal yang lebih tinggi dengan diperoleh nilai (mean $=73,36$ ) dibandingkan dengan kelompok sampel remaja yang memiliki orangtua tidak lengkap diperoleh nilai $($ mean $=63,21)$. Dengan demikian hasil penenilitian ini menunjukkan bahwa remaja yang memiliki orangtua lengkap memiliki kecerdasan yang lebih tinggi dibandingkan dengan remaja orangtua tidak lengkap.

Berdasakan hasil analisis tambahan kecerdasan interpersonal pada subjek laki-laki menunjukkan $\mathrm{N}=96$, Mean=68,15, $S D=11,176$. Kecerdasan interpersonal pada subjek perempuan menunjukkan $\mathrm{N}=89$, Mean=69,29, SD=12,608. Jadi dapat disimpulkan kecerdasan inerpersonal pada subjek laki-laki dan perempuan menunjukkan tidak terdapat perbedaan. Hal ini terlihat dari hasil analisis yang menunjukkan tidak ada perbedaan nilai yang singnifikan antara subjek laki-laki dan subjek perempuan.

Peneliti juga melakukan analisis tambahan pada subjek laki-laki yang memiliki orangtua lengkap dengan subjek laki-laki yang memiliki orangtua tidak lengkap. Hasil analisis pada subjek laki-laki yang memiliki orangtua lengkap diperoleh nilai $\mathrm{N}=61$, Mean $=72,89$, $S D=0.993$, sedangkan pada subjek laki-laki yang memiliki orangtua tidak lengkap diperoleh nilai $\mathrm{N}=35$, Mean $=59,89$, $\mathrm{SD}=1,945$. Dari hasil yang analisis yang telah dilakukan menunjukkan bahwa terdapat perbedaan kecerdasan interpersonal antara subjek laki-laki yang memiliki orangtua lengkap dengan subjek laki-laki yang tidak memiliki orangtua lengkap.

Selanjutnya analisis tambahan yang dilakukan peneliti pada subjek remaja perempuan yang memiliki orangtua lengkap dengan subjek perempuan yang memiliki orangtua tidak lengkap. Hasil analisis pada subjek perempuan yang memiliki orangtua lengkap diperoleh nilai $\mathrm{N}=39$. Mean=74,10, $\mathrm{SD}=1,152$, sedangkan pada subjek perempuan yang memiliki orangtua tidak lengkap diperoleh nilai
$\mathrm{N}=49$, Mean=65,63, SD=2,052.

Berdasarkan hasil analisis di atas menunjukkan bahwa terdapat perbedaan kecerdasan interpersonal yang signifikan antara remaja perempuan yang memiliki orangtua lengkap dengan remaja perempuan yang memiliki orangtua tidak lengkap.

\section{Pembahasan}

Hasil penelitian menunjukkan bahwa hipotesis diterima, yaitu terdapat perbedaan kecerdasan interpersonal pada remaja yang memiliki orangtua lengkap dengan remaja yang tidak memiliki orangtua lengkap. Kemudian pada analisis tambahan pada remaja yang memiliki orang tua lengkap ditemukan nilai mean yang tidak jauh berbeda antara laki-laki dan perempuan. Artinya berdasarkan jenis kelamin secara keseluruhan menunjukkan bahwa tidak terdapat perbedaan kecerdasan interpersonal pada laki-laki dan perempuan. Namun pada remaja yang tidak memiliki orangtua lengkap menunjukkan bahwa terdapat perbedaan yang signifikan antara subjek remaja laki-laki dengan subjek remaja perempuan. Begitu juga selanjutnya dengan analisis tambahan bada subjek lakilaki orangtua lengkap dengan subjek remaja laki-laki yang memiliki orangtua tidak lengkap dan analisis antara subjek remaja perempuan yang memiliki orangtua lengkap dengan subjek remaja yang tidak memiliki orangtua lengkap menunjukkan adanya perbedaan kecerdasan interpersonal yang signifikan.

Kecerdasan interpersonal merupakan kemampuan untuk mengenali dan membuat perbedaan antara perasaan, kepercayaan, dan keinginan orang lain. Anderson (1999) mengatakan kecerdasan interpersonal ini mempunyai tiga dimensi utama yaitu: social sensitivity, social insight, dan social communications ketiga dimensi ini merupakan satu kesatuan yang utuh dan saling mengisi satu sama lain.

Pada penelitian ini menunjukkan adanya perbedaan kecerdasan interpersonal remaja yang memiliki orangtua lengkap dengan yang tidak lengkap, artinya bahwa remaja yang memiliki orangtua lengkap memiliki kecerdasan interpersonal yang lebih baik dibandingkan dengan remaja yang memiliki orangtua tidak lengkap. Hasil ini menggambarkan bahwa pentingnya keberadaan orang tua secara penuh baik ayah maupun ibu untuk membentuk kecerdasan interpersonal remaja. Data temuan ini sejalan dengan hasil penelitian yang dilakukan oleh Purnama (2007), ada hubungan yang sangat signifikan antara kecerdasan interpersonal terhadap efektivitas komunikasi pada orangtua.

Penelitian lain yang dilakukan oleh Mclanahan dan Sanderfur (dalam Isnani, 
2013), remaja yang tinggal bersama orangtua tunggal atau remaja yang tidak memiliki orangtua lengkap memiliki dua kali lipat kemungkinan untuk putus sekolah, dua kali lipat kemungkinan menjadi pengangguran (keluar dari sekolah), melanggar aturan yang ada di sekolah, menunjukkan perilaku yang menyimpang. Penelitian ini menggambarkan remaja dengan orang tua tidak lengkap beresiko melanggar aturan sosial dimasyarakat. Remaja yang memiliki kecerdasan interpersonal yang rendah sering melanggar aturan-aturan yang ada di lingkungan sosialnya, tidak memiliki tujuan hidup, dan menunjukkan perilaku yang tidak sesuai dengan lingkungan sekitarnya.

Remaja yang memiliki kecerdasan interpersonal yang tinggi memiliki kemampuan dalam berkomunikasi mencakup komunikasi verbal dan non verbal. Pada penelitian yang dilakukan oleh Ayu'ni (2010) dalam penelitiannya menunjukkan bahwa remaja yang berasal dari keluarga lengkap menunjukkan remaja yang memiliki kemampuan dalam berkomunikasi dengan orang lain secara baik, mampu mengungkapkan perasaan-perasaan yang dirasakan secara baik, dan sebaliknya. Temuan di atas sejalan dengan penelitian ini dalam penelitian ini terdapat perbedaan yang singnifikan antara kecerdasan pada remaja yang memiliki orangtua lengkap dengan tidak lengkap. Dimana remaja yang memiliki orangtua lengkap mampu berkomunikasi dengan baik, mampu menjalin hubungan yang baik dengan orang lain, mampu bersosialisasi, menunjukkan kegembiraan, aktif, terbuka dan sebaliknya dengan remaja yang memiliki oragtua tidak lengkap.

Selain itu ketidaklengkapan orangtua akan mengurangi salah satu fungsi dari orangtua baik ayah maupun ibu, sehingga keberadaan keluarga lengkap menjadi sangat penting dalam perkembangan remaja selanjutnya. Keberadaan akan ayah dan ibu dalam satu keluarga akan membimbing, mengarahkan serta serta membentuk kepribadian remaja hingga mampu melakukan penyesuain diri yang baik, mampu menjalin hubungan yang baik dengan orang lain, dan mampu mengungkapkan pendapat dan keinginananya. Hal ini bisa menyebabkan remaja yang memiliki keluarga tidak lengkap memiliki tingkat kecerdasan interpersoanal yang lebih rendah dari pada remaja dari keluarga lengkap.

Menurut Qiami (dalam Ayu'ni, 2010) ada beberapa dampak atau pengaruh yang menimpa keluarga dan anak-anak kehilangan salah satu orangtua baik ayah dan ibu, pengaruhnya secara mental dan kejiwaan bisa berupa menurunnya kecerdasan (termasuk kecerdasan interpersonal), harapan dan semangat, sedangkan pada perasaan akan muncul rasa gelisah, ketakutan, depresi bahkan kehilagan rasa belas kasih. Sehingga remaja yang memiliki orangtua tidak lengkap menunjukkan memiliki kecerdasan interpersonal yang rendah dibandingkan remaja yang memiliki orangtua lengkap.

Mengingat kecerdasan interpersonal tidak otomatis dibawa sejak lahir, maka untuk memperoleh, mengasah dan mengembangan kecerdasan interpersonal di butuhkan proses pembelajaran yang berkesinambungan. Remaja perlu dilatih untuk mengembangkan kecerdasan interpersonalnya dan keterampilan sosialnya. Peran Orangtua sangat berperan penting dalam membantu mengembangkan kecerdasan interpersonal pada remaja, agar remaja memiliki kecerdasan interpersonal yang baik. (Muniroh 2010).

Remaja perlu memiliki kecerdasan interpersonal yang tinggi agar mampu dan terampil bergaul dengan lingkungan disekitarnya. Kecerdasan interpersonal diperoleh melalui proses belajar yang berkesinambungan. Remaja perlu dilatih untuk mengembangkan keterampilan sosialnya. Orangtua yang memberikan bimbingan melalui keteladanan dan dukungan terhadap remaja. Agar remaja mampu mengembangkan kecerdasan interpersonalnya secara baik (Safaria, 2005). Ketika remaja menghadapi kesulitan dalam me nyesuaikan diri dengan lingkungannya menunjukkan rendahnya kemampuan interpersonalnya atau yang disebut dengan kecerdasan interpersonal dan remaja dengan kecerdasan interpersonal yang rendah akan kurang mampu menjaᄀlin komunikasi yang efektif dengan orang lain, berempati dengan baik kepada orang lain, serta kurang mampu mengembangkan hubungan yang harmonis dengan orang lain. Namun berbeda ketika remaja memiliki kecerdasan interpersonal yang tinggi. Mereka lebih mampu menjalin komunikasi yang efektif dengan orang lain, mampu berempati secara baik, mampu mengem $\neg$ bangkan hubungan yang harmonis dengan orang lain. Mereka juga dapat dengan cepat memahami temperamen, sifat dan kepribadian orang lain serta mampu memahami suasana hati, motif dan niat orang lain (Rozali, 2015).

Remaja yang memiliki kedua orangtua lengkap yang selalu memberikan perhatian yang lebih, dan mendidik anaknya dengan baik akan memberikan pengaruh yang sangat kuat dan mampu menciptakan remaja yang luar biasa, mampu membuat remaja mengenali dirinya sendiri dengan konsep diri yang jelas sehingga dapat menunjukkan kemampuannya dalam membina komunikasi dengan baik. Sehingga remaja mampu menjalin hubungan sosial yang baik dengan oranglain ataupun lingkungan sosial di sekitarnya.

Keberadaan orangtua lengkap dan tidak lengkap pada penelitian ini menunjukkan adanya konstribusi yang besar terhadap 
kecerdasan interpersonal remaja. Hal ini terlihat dari hasil penelitian yang telah dilakukan oleh peneliti. Bahawa remaja yang memiliki orangtua lengkap memiliki kecerdasan interpersonal lebih tinggi dibandingkan dengan remaja yang memiliki orangtua tidak lengkap. Berdasarkan hasil analisis kategorisasi juga menunjukkan adanya perbedaan antara remaja dengan orangtua lengkap dan remaja dengan orangtua tidak lengkap berdasarkan dimensi kecerdasan interpersonal yaitu: social sensitivity, social insight dan social communication. Hasil menunjukkan bahwa remaja yang memiliki orangtua lengkap memiliki social sensitivity lebih baik dari pada remaja yang tidak memiliki orangtua lengkap. Remaja yang memiliki orangtua lengkap mampu merasakan dan mengamati reaksi-reaksi atau perubahan orang lain yang ditunjukkannya baik secara verbal maupun non-verbal, memiliki sikap empati dan prososial (Anderson, 1999).

Kemudian pada remaja yang memiliki orangtua lengkap memiliki social insight lebih baik dibandingkan dengan remaja yang tidak memiliki orangtua lengkap. Remaja dengan sosial insight yang baik mampu untuk memahami dan mencari pemecahan masalah yang efektif dalam suatu interaksi sosial, memiliki kesadaran diri, mampu memahami situasi sosial dan memiliki keterampilan pemecahan masalah. (Anderson, 1999).

Selanjutnya remaja yang memiliki orangtua lengkap juga memiliki social communication atau kemampuan berkomunikasi yang lebih baik dan efektif dibandingkan dengan remaja yang tidak memiliki orangtua lengkap. Sehingga dapat terlihat perbedaan kecerdasan interpersonal pada remaja yang memiliki orangtua lengkap dengan remaja yang tidak memiliki oragtua lengkap.

\section{Kesimpulan}

Berdasarkan hasil penelitian ini, maka dapat ditarik kesimpulan bahwa terdapat perbedaan kecerdasan interpersonal pada remaja yang memiliki orangtua lengkap dengan remaja yang tidak memiliki orangtua lengkap. Artinya keberadaan orangtua lengkap dan tidak lengkap memberikan konstribusi terhadap kecerdasan interpersonal remaja. Berdasarkan analisis yang telah dilakukan pada subjek laki-laki dan perempuan secara keseluruhan dalam penelitian ini tidak terdapat perbedaan kecerdasan interpersonal mereka. Selanjutnya hasil analisis tambahan berdasarkan jenis kelamin pada subjek laki-laki yang memiliki orangtua tidak lengkap dengan subjek perempuan yang memiliki orangtua tidak lengkap menunjukkan adanya perbedaan, begitu juga hasil analisis pada subjek remaja laki-laki yang memiliki orang- tua lengkap dengan tidak lengkap dan analisis tambahan pada subjek remaja perempuan yang memiliki orangtua lengkap dengan perempuan yang memiliki orangtua tidak lengkap terdapat perbedaan kecerdasan interpersonal yang signifikan.

\section{Daftar Pustaka}

Amsrong. (2002), Setiap Anak Cerdas: Panduan Membantu anak Belajar Dengan Memanfaatkan Multiple Intelligencesnya, ter, Rina Buntara, Jakarta, Gramedia Pustaka Utama.

Anderson, M. (1999). The Development Of Intelligence. Uk. Psychological Pers.

Arikunto, S. (2010). Prosedur Penelitian, Suatu Pendekatan Praktik, Jakarta. PT Renika Cipta.

Arikunto, S. (2002). Prosedur Penelitian, Suatu Pendekatan Praktek. Jakarta. PT Rineka Cipta.

A Rozali, Yuli. (2015). Kecerdasan Interpersonal Remaja Ditinjau Dari Penerapan Pola Asuh Orangtua. Psycholog, Forum UMM ISBN: 978-979-976-3248, Universitas Esa Unggul. Jakarta.

Azwar, S. (2009). Reliabilitas dan Validitas. Yogyakarta: PustakaPelajar.

------. (2010). Metode Penelitian. Yogyakarta: Pustaka Pelajar

(2012). Penyusunan Skala Psikologi. Yogyakarta: Pustaka Pelajar

A'yuni,Quratul (2010). Perbedaan Tingkat arsetivitas antara Siswa dari Keluarga Lengkap dengan Siswa dari Keluarga Single Parent di SMK Negeri 1 Pakong Pamekasan Madura. Universitas Islam Negeri Maualana Malik Ibrahim, Malang.

Budi Dwi L (2010). Agresifitas Remaja yang Memiliki Orang Tua Tunggal (Single Parent) Wanita. Universitas Gunadarma.

Dagun, S (2002). Psikologi Keluarga. Penerbit Rineka Cipta. Jakarta.

Gowi, Abdul. (2011). Pengaruh latihan asertif terhadap perilaku kekerasan orang tua pada anak usia sekolah di kelurahan tanjung pura kabupaten karawang. Depok : Tesis Psikologi UI.

Gozali. (2011). Kecerdasan Intrapersonal Menurut Para Ahli.http://gozali gunadarma. blogspot.com/2011/11/ pengertian-kecerdasan-interpersonal. html. Jum'at 24 Mei 2013 10:30.

Isnaini Ismi M, (2013). Perbedaan Harga Diri (Self Esteem) Remaja Ditinjau Dari Keberadaan Ayah. Jurnal Psikologi, Vol 9 No 2

Kiftirul, Aziz,Dkk, (2010). Hubungan Antara Kecerdasan Interpersonal, Berpikir Kreatif, dan hasil Menulis Siswa kelas 
V SD Negeri di Kabupaten Kebumen. UniversitasNegeri Sebelas Maret.

Misbach, I, H. (2010).Dahsyatnya Sidik Jari, Jakarta: Visimedia.

Muniroh, MS. (2010). Pengembangan Kecerdasan Interpersonal Anak. Sekolah Tinggi Agama Islam Negeri: Artikel. Pekalongan.

Purnama Ayu S. (2007). Hubungan Antara Kecerdasan Interpersonal Remaja Dengan Efektivitas Komunikasi Pada Orangtua Pada Mahasiswa Fakultas
Psikologi Angkatan 2004-2006

Universitas Islam Negeri (UIN)

Malang. Malang, Skripsi. Fakultas

Psikologi Universitas Islam Negeri (UIN) Malang.

Safaria.(2005). Interpersonal Intelligence. Yogyakarta: Amara Books.

Sugiyono. (1994). Statistika Untuk Penelitian. Bandung: CV. Alfabeta

Yusuf, S. (2011). Psikologi Remaja; Perkembangan Peserta Didik. Jakarta: Bumi Aksara. 